\title{
Improving Passive Solar Housing Design to Achieve Energy Efficiency; Case Study: Famagusta, North Cyprus
}

\author{
Mojdeh Nikoofam ${ }^{1, *}$, Abdollah Mobaraki \\ ${ }^{1}$ Department of Architecture, Faculty of Architecture, Eastern Mediterranean University, Turkey \\ ${ }^{2}$ Department of Architecture, Faculty of Fine Arts, Design and Architecture, Cyprus international University, Turkey
}

Received February 12, 2021; Revised March 23, 2021; Accepted May 11, 2021

\section{Cite This Paper in the following Citation Styles}

(a): [1] Mojdeh Nikoofam, Abdollah Mobaraki, "Improving Passive Solar Housing Design to Achieve Energy Efficiency; Case Study: Famagusta, North Cyprus," Civil Engineering and Architecture, Vol. 9, No. 4, pp. 1064 - 1074, 2021. DOI: 10.13189/cea.2021.090409.

(b): Mojdeh Nikoofam, Abdollah Mobaraki (2021). Improving Passive Solar Housing Design to Achieve Energy Efficiency; Case Study: Famagusta, North Cyprus. Civil Engineering and Architecture, 9(4), 1064 - 1074. DOI: 10.13189/cea.2021.090409.

Copyright $(2021$ by authors, all rights reserved. Authors agree that this article remains permanently open access under the terms of the Creative Commons Attribution License 4.0 International License

\begin{abstract}
The significant aim of architecture is to support different human needs especially housing as an essential requirement; as well as the consideration of environmental factors. One of the environmental issues is the consideration of climatic conditions that have a deep influence on designing to create comfortable indoor spaces and housing durability. Based on climate conditions, passive solar energy as primary factor decreases energy consumption inexpensively. Furthermore, it is undeniable that socio-cultural structure of the society has deep influence on designing houses. The purpose of this study is to investigate how to improve housing quality for achieving low-cost energy by use of endless energies as a potential point in Famagusta with Mediterranean climate. Moreover, the second part of paper is the considered strategies in different period of Cypriot dwelling, as an important strategy in comparison evaluation.
\end{abstract}

Keywords Housing Design, Passive Solar Energy, Energy Efficiency, Comfortable Indoor Spaces

\section{Introduction}

The environmental factor is the most significant influence on individuals because there is a strong link between human being, and their environment. In order to make more sustainable qualities, our environment should take into consideration for designing houses. Generally, when designers want to make harmony between human and their environment, local climate is the initial factor. Because, climate is the most important part of individual's environment and it has significant effect on housing design to achieve energy consumption. N. Ozay [1] mentioned that housing design is considered climatically to decrease energy consumption, utilize renewable energy instead of fossil fuels and providing more sustainable, comfortable and healthier indoor spaces as well as outdoors. Therefore, the first consideration of design is passive solar design that it is the most effective design to create comfortable building environment and increase energy efficiency according to local climate and environmental response. Passive solar heating system, natural cooling techniques and systems for natural lighting are three categorizes of passive solar systems to create comfortable indoor temperature, and optimize energy consumption. Besides, the domestic sectors are using more than 45 percent of the total energy demand thus applying passive solar energy strategy in design can decrease energy consumption, and cost of energy as well $[2,3,4]$. The research is defined various strategies can be applied to enhance passive solar housing design in order to improve the quality of housing in respect of the future 
generation requirements of energy. Thus, in the first part of the study, housing design is considered the principles of passive solar housing design like location and microclimate, building orientation, physical characteristics of opening such as their proportion and shading elements, suitable type of vegetation, and effective parameters on the performance of thermal mass based on the climate condition of Famagusta city. Also, the investigated strategies will be discussed in the most remarkable period of Cypriot housing which are: Ottomon, British and Modern period in the second part of paper (Figure 1).

\section{Passive Solar Housing Design}

Passive solar building is designed to use of renewable energy such as sun and wind in terms of the local climate to achieve the items which mentioned below:

- $\quad$ Provide a comfortable indoor temperature;

- Optimize energy consumption;

- Increasing environmentally responsible with maintaining built environment and decreasing carbon dioxide emission to create a healthy space for users;

- Improving flexibility toward adding active solar energy systems if it is needed.

Passive solar strategies should be considered at the initial stages of design to be effective for the dwellers. Famagusta has the potential point to utilize this system in order to achieve the mentioned goals but lack of climate consideration is obvious in the most recent building. Unfortunately, it is mentioned by C. Koroneos et al., [5] that most of Cypriot people rely on fuel energies for heating and cooling indoor environment. Therefore, in the following context is considered the importance strategy of passive solar energy.

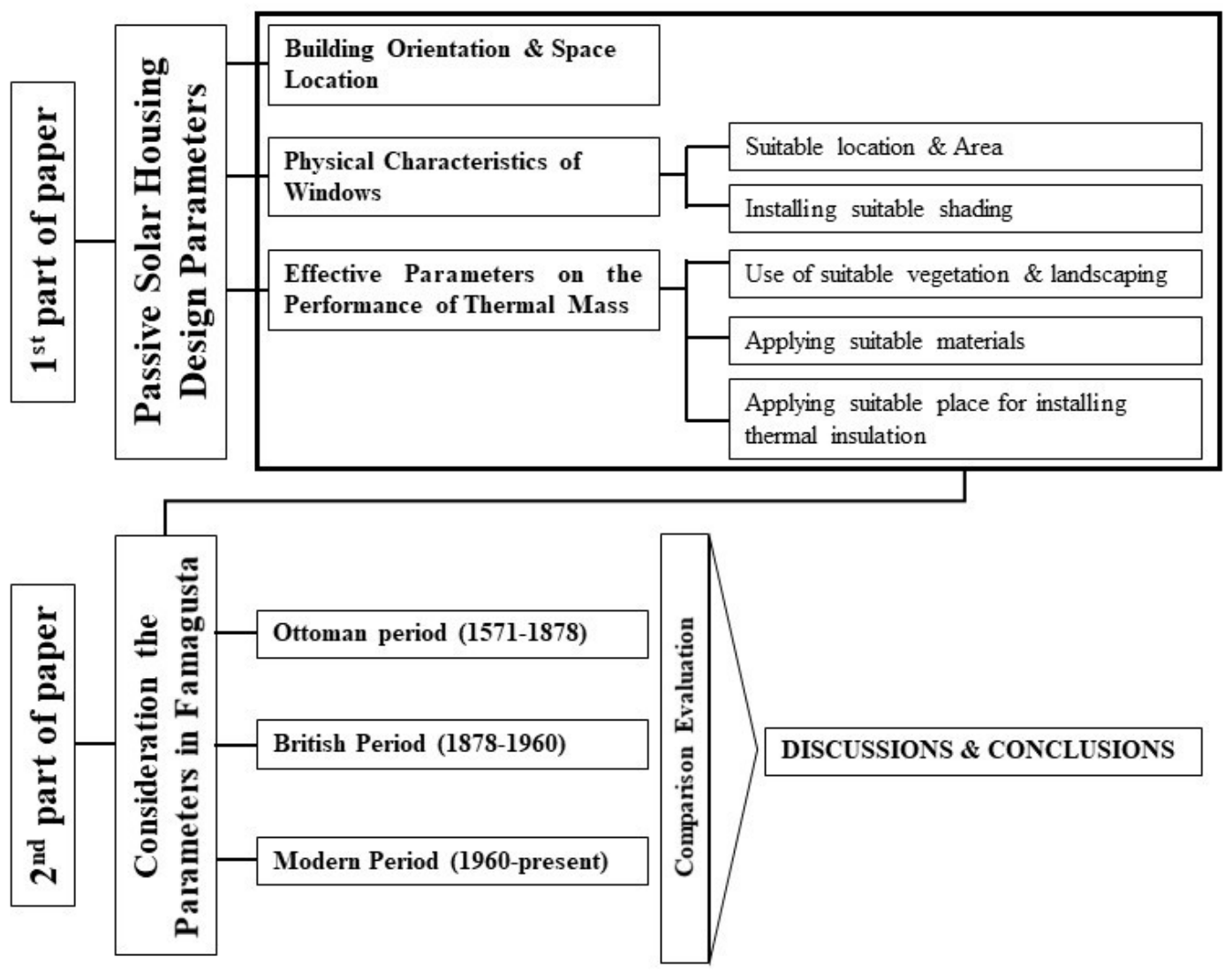

Figure 1. Structure of the Paper 


\begin{tabular}{|c|c|c|c|c|c|c|c|c|c|c|c|c|c|}
\hline \multicolumn{14}{|c|}{$\begin{array}{l}\text { FAMAGUSTA } \\
\text { Location: } 35^{\circ} \mathrm{N} \text { Latitude } 34^{\circ} \mathrm{E} \text { Longitude } \\
\text { Height Above Sea Level: } 7 \mathrm{~m}\end{array}$} \\
\hline MONTHS & 1 & 2 & 3 & 4 & 5 & 6 & 7 & 8 & 9 & 10 & 11 & 12 & \\
\hline Sunshine Period (hour/Day) & 5.5 & 6.2 & 7.0 & 8.4 & 10.1 & 11.8 & 12.4 & 11.6 & 10.2 & 8.3 & 6.6 & 5.1 & \\
\hline Cloud Cover & 6 & 5 & 5 & 4.4 & 4 & 2.5 & 2 & 1.5 & 2 & 3 & 4 & 5.5 & \\
\hline \multicolumn{14}{|l|}{ Solar Radiation Intensity W/m2 } \\
\hline Total Solar Radiation (MJ/M2 day) & 7 & 10 & 14 & 18 & 23 & 24 & 24 & 23 & 18 & 14 & 9 & 6.5 & \\
\hline Mean Max Air Temperature $\left({ }^{\circ} \mathrm{C}\right)$ & 16.4 & 16.4 & 18.4 & 22.2 & 26.5 & 30.6 & 33.1 & 33.3 & 31.1 & 27.2 & 22.0 & 17.6 & \\
\hline Mean Min Air Temperature $\left({ }^{\circ} \mathrm{C}\right)$ & 6.9 & 6.5 & 7.8 & 10.5 & 14.2 & 18.4 & 21.1 & 21.4 & 16.4 & 15.3 & 11.0 & 7.5 & \\
\hline 14.00Hours Relative Humidity (\%) & 60 & 60 & 57 & 52 & 48 & 47 & 45 & 46 & 48 & 52 & 55 & 60 & \\
\hline Mean Relative Humidity (\%) & 72.8 & 71.7 & 72.8 & 70.7 & 67.3 & 64.3 & 65.0 & 67.3 & 66.6 & 67.5 & 70.0 & 73.2 & \\
\hline 7.00Hours Relative Humidity (\%) & 88 & 89 & 84 & 89 & 90 & 88 & 85 & 88 & 86 & 86 & 88 & 87 & \\
\hline Precipitation (Mm/month) & 57.2 & 54.5 & 40.9 & 17.9 & 10.2 & 4.1 & 0.8 & 0.6 & 1.1 & 17.8 & 45.4 & 81.9 & 332 \\
\hline Predominant Wind Direction & $\mathrm{W}$ & $\mathrm{W}$ & W & $\mathrm{W}$ & $\mathrm{W}$ & SW & SW & SW & W & W & $\mathrm{W}$ & $\mathrm{W}$ & \\
\hline
\end{tabular}

Figure 2. Climatic Data of Famagusta

\subsection{Location and Microclimate}

If housing is completed to apply the effective point of local climate and decrease annoying factors related to climatic aspect, most of problems can be removed. Every region has special climatic conditions which have significant effect on designing a house. Famagusta is located at around $35^{\circ} \mathrm{N}$ Latitude $34^{\circ} \mathrm{E}$ Longitude.

As it is clear in Figure 2, Famagusta reflects the characteristics of hot humid climate with hot-dry summers and rainy winters although the city is located at transitional zones between hot-humid and composite climates in comparison with other cities in North Cyprus [5]. Also, he is mentioned that the town has very high relative humidity level in early time of day and during night time. The prevailing wind comes from west and south-west in a year and relative humidity is between 64 and 73. The city has maximum rainfalls Between December and March. In addition, the city has a little cloudy sky and most of time has clean sky to apply high intensity of direct sun radiation [7].

\subsection{Building Orientation and Space Location}

It is mentioned by R. M. Pulselli et al., [9] passive solar housing is able to reduce energy consumption and orientation is the most significant option in order to apply passive solar issue in housing design. Besides, appropriate orientation is the most fundamental way that should be considered at initial stage of design proceeding and suitable orientation can be accomplished inexpensively to optimize energy use especially in less benign climate [10]. As I. Spanos et al., [11] stated energy requirements can be decreased approximately 20 percent by good orientation, location of building on site or urban domain and landscaping. Orientation consideration is not a new issue, many scholars tried to consider good orientation for building according to northern or southern hemisphere, position of sun, the length of day and night in different seasons. They evaluated suitable orientation to achieve sun's radiation for heating the spaces during the winter and good daylight in summer.
In addition, air movement is one of the effective factors to achieve human thermal comfort that good orientation provides air movement by natural ventilation with opening. Natural ventilation as a passive cooling technique direct cool air from outside into the building during night time to provide an excellent cooling and reduce cooling energy use during day [12-14]. Therefore, good ventilation decreases the amount of energy for cooling during hot seasons especially in hot-humid temperature.

Famagusta is located at northern hemisphere perspective, facing south has important impact on the energy behavior of a house because the southern orientation increases availability of daylight and heating benefits from sun radiation during winter and the eastern has healthful quality as well. The main openings should be located at southern façade of buildings however the northern one contains less area with a few openings. Where the residents of building spent much time in the spaces, the spaces should be accommodated in southern face like living room, dining room and bedrooms. On the other hand, stores and circulation spaces should be situated in northern façade. Different orientation of building effect on the amount of received solar radiation [15]. In general, if the long axis of building lies along east-west direction, the building has ideal orientation in Famagusta. Also, the longest axis should incline $15^{\circ}$ to west direction provide good ventilation in summer and enough heat of solar radiation during winter because of prevailing wind.

Generally appropriate orientation is able to provide enough daylight and good ventilation by suitable opening. Enough daylight has deep influence on environmental issues, energy consumption, aesthetical concepts and human's psychology and natural ventilation can provide suitable air movement for improving indoor air quality.

\subsection{Physical Characteristics of Windows}

Appropriate location and area of windows play a significant role in passive design housing for saving 
energy because appropriate opening can 1) penetrate the highest amount of natural lighting, and 2) provide natural ventilation for increasing thermal comfort. Also, using of suitable shading devices can control over heating of indoor spaces. Consideration day lighting has deep influence on housing design that they support following factors:

- Increasing the quality of healthy life with respecting to our environment;

- Decreasing cost of energy and saving energy;

- Providing physiological and psychological effect on the occupants with applying aesthetical consideration.

As it is mentioned, the biggest windows should be located at south face. The south openings provide valuable day lighting for indoor spaces to make easy heating in cold season and well-lit spaces in summer because of different angle of winter and summer sun radiation. Also, pitched roof with suitable overhang high and high ceiling apply sun control to increase thermal comfort during hot seasons in south façade although it allows penetrating sun radiation in winter [16] (Figure 3). Some spaces can get benefits from a direct sun for heating and lighting, are located in south façade such as living rooms, dining rooms, and bedrooms. The windows in eastern façade improve the quality of indoor spaces early morning time. Windows are located at north and west façade to be able provide cross ventilation that it is necessary for hot-humid climate. Besides, the area of the opening should be minimized to create glare control. Some spaces are located in north direction need low amount of lighting and heating like stair boxes, stores and garage wherever just passing them.

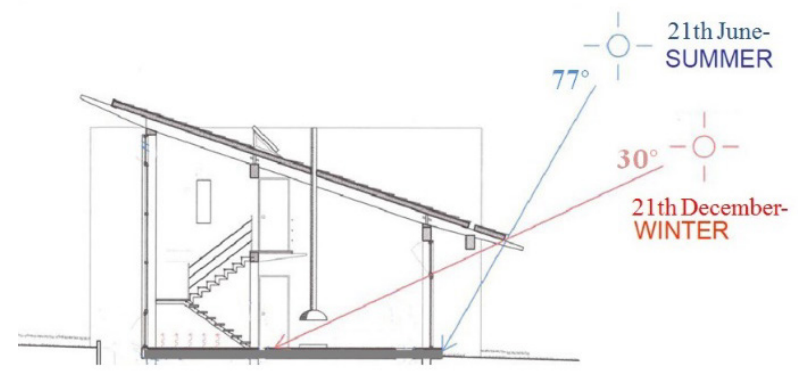

Figure 3. The Role of Roof Eave in South Direction in Sun Control for Summer

In addition, in order to achieve comfortable indoor temperature, vegetation and greenery is used to provide evaporative cooling and they are able to provide shadow spaces as well [17]. It is more acceptable that sun control of west and north façade is applied by trees instead of shading devices. They are embedded in building to increase comfort and health of indoor spaces as green walls. However, limited water supply is an important problem in the city. Therefore, deciduous trees are the best type of greenery because this type of trees needs less water. In addition, the trees let sun radiation to warm building in winter because of losing their leaves [18]. Also, as it is clear in Figure 4, deciduous trees provide enough shading in the summer and greenery can reduce cooling and heating energy use by $25 \%$ [19].

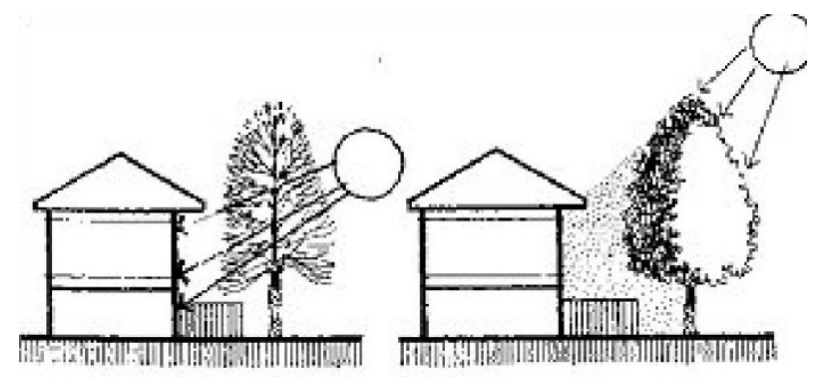

Figure 4. Suitable Examples of Landscape to Decrease Over-Heating

\subsection{Effective Parameters on the Performance of Thermal Mass}

Various components of the buildings such as windows, walls, roof and doors are the most crucial sources to lose or gain annoying heat to indoor spaces because they are exposed to the direct sun radiation [20]. Also, material of building may reflect sound, moisture, and thermal considerations. Therefore, appropriate building material and design of their component have significant influence on thermal comfort. Considering the amount of solar energy is done to achieve passive solar housing design according to local climatic aspects and suitable materials to keep thermally comfortable environments [7,8]. Selected suitable material and installing thermal insulation for component of housing provide comfortable indoor spaces for the users. Material building should have high resistance in hot-humid climate because the material mostly faces with damage and mold [21,22].

Khudhair and Farid [23] express that appropriate materials decrease energy consumption by applying thermal mass which have valuable influence on indoor temperature. For instance, some material store solar gain during day and in night time, the temperature of indoor environment is increased by releasing stored heat that the mechanism reduces energy for heating during winter. Also, storing heat is able to decrease energy demands for cooling in hot seasons like concrete and adobe [23]. According to receiving direct or indirect solar radiation and suitable time leg, the type of material building should be chosen [24]. C. A. Balaras [21] stated that the surface materials of north and east direction need to have little time lag but south and west surfaces should delay transferring of stored heat about 8 hours. Also, he mentioned that roof of housing requires massive construction with a long-time leg because most time of a day, the component receive directly solar radiation. Concrete and stone are the best material building in hot-humid climate because these materials not only retard diffusion of moisture but also provide passive thermal comfort in indoor environment. Although, timber is poor 
conductors of heat, use of timber in floors and ceiling contribute to the thermal mass by moderating heat gains. Besides, about 30 percent of cooling energy demand will be decreased about 30 percent if designers apply white or light color for materials [25,26].

In addition, thermal insulation is used toward the inner layers of building component where warm seasons are longer than the cool ones because they catch sunshine in the external layers during the day in order to increase thermal comfort and release the stored heat during night time when the temperature suddenly falls down.

\section{Assessment Passive Solar Housing Design in Cypriot Housing during Different Period}

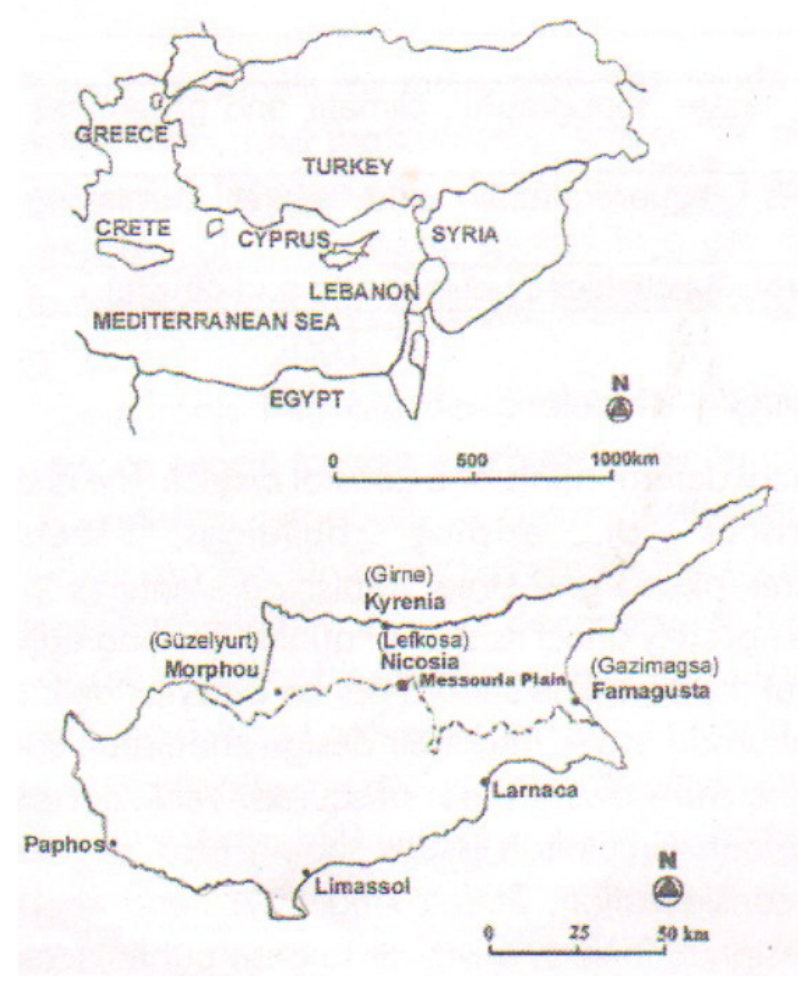

Figure 5. Location of Famagusta at Cyprus [28]

Lying on the east of Mediterranean Sea, Famagusta counts as the second largest town of N. Cyprus (Figure 5). Its history is assessed in seven periods including [27]:
1. Through 648-1192 AD, the eldest settlements were founded.

2. The Lusignan period lasted from 1192 to 1489 . The city is developed based on its harbor, the Mediterranean Sea and the fortified wall.

3. Next Lusignan era until 1571 was entitled Venetian period. The period had had significant influence in sociocultural life by the style of architecture.

4. Between 1571-1878 was called the Ottoman because Famagusta was occupied by Ottoman.

5. The British period was lasted during 1878-1960 when Famagusta was appeared as a modern coastal city.

6. Also, by the ending of the British era (1960-1974), a drastic change in form and style took place. And,

7. The last era is occurred after 1974.

Ottoman, British and Modern are the most important architectural periods that they have deep influence on designing the traditional dwelling.

\subsection{The Ottoman Period}

Ottomans were the pioneers to start constructing their own houses. The architectural design of housing in the period has many physical harmonies with traditional Turkish houses and their different design reflected the climatic aspect of the region. Most of the houses in the period are completely parallel in designing, some rooms are located around a courtyard that these spaces are applied for different activities as flexible units. The inner courtyard is called havli in Cypriot settlement and avlu in local Turkish where is covered by palm trees, small vegetables and flowers to provide access to nature and shadow for cooling the building. Also, the courtyards provide a coherent social organization for members of occupants, making food and drying laundry for their dwellers and the spaces can provide air velocity, evaporative cooler, shaded spaces and climatically comfortable area for the users [29]. The building materials are adobe and yellow stones for walls also marble and woods for floors in terms of availability and climatic aspects of the region. R. Raycheva [30] mentioned that thick adobe walls, pitched roof with overhangs as a shading element, cikma or cumba (bay window), and high ceiling are the climatic characteristics of the building design during Ottoman period (Figure 6). 

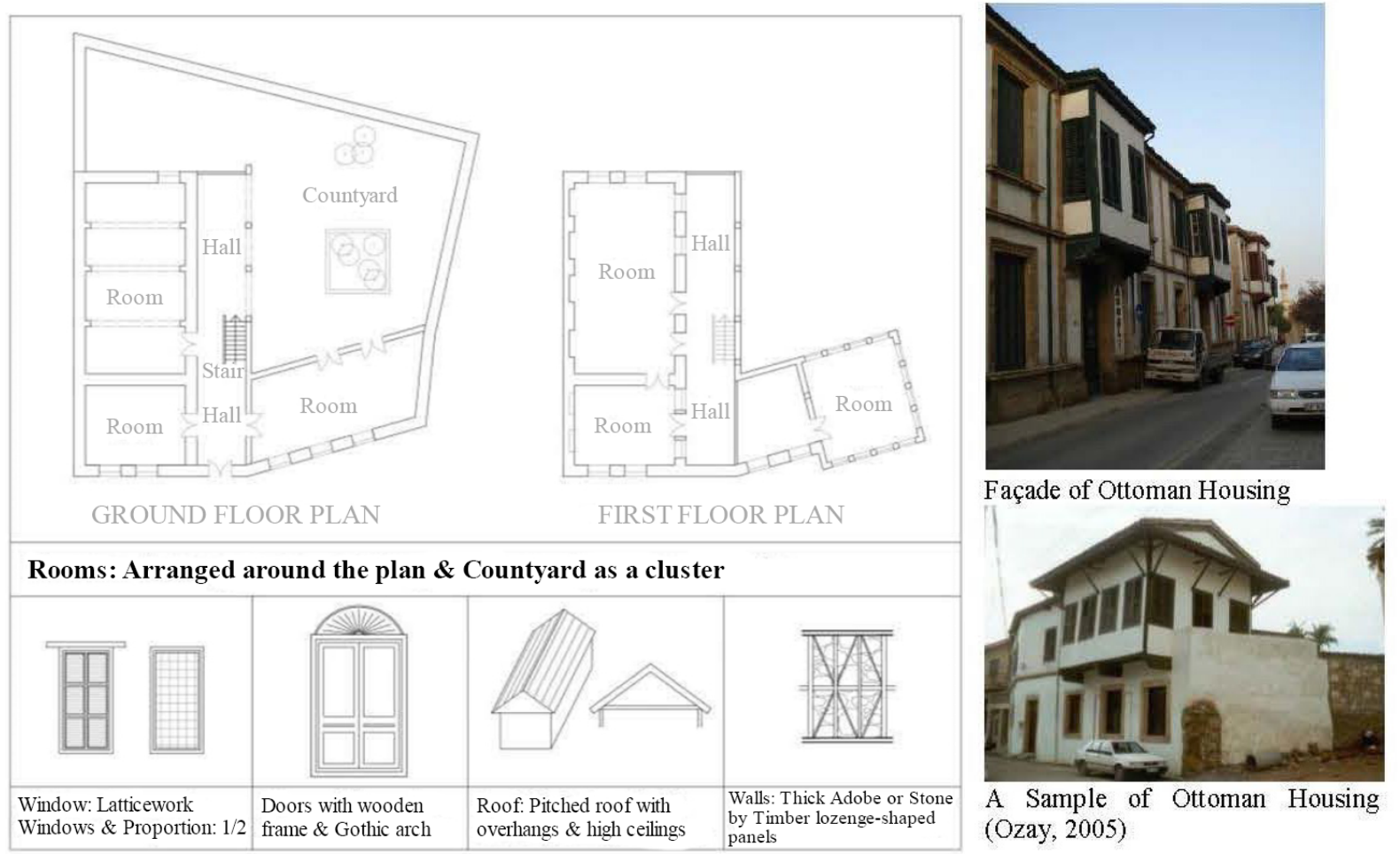

Figure 6. A Sample of Ottoman Housing is Available at Archive of the Department of Ancient Monuments and Museums (Developed by Researcher)

Orientation of building was ignored during the period and in order to decrease heating load, they tried to construct compact building and urban domain to increase shadow spaces in these spaces. Also, courtyards were the other strategy where is installed to provide solar insolation during hot seasons. However, the spaces impeded cross ventilation which has significant influence on creating comfortable and healthy indoor spaces in hot-humid climate. Besides, the housing spaces were not dedicated for special function because the indoor spaces as flexible unites were applied for various functions in different season. According to availability, the surface building is covered by adobe, yellow stone and timber as material buildings that the materials had good performance in the climate as storage mass. In addition, about 9 percent of surfaces were embedded opening or windows so the windows area was not appropriate in the period.

\subsection{The British Period}

The British period appeared after three hundred of the Ottoman era that the period was established by innovated techniques and material in Cypriot housing design [1]. As it is mentioned by W. Dreghorn [31], the British era is divided in two periods: the first one lasted from 1878 to 1930 and the second one is between 1930-1960. Building of the first period is quite continued Ottoman features and styles in architectural design with little changes refer to British culture. Fortunately, designers were emphasized on good orientation and suitable space location as fundamental strategy of passive solar energy in the period which was ignored in previous one. In order to strong cross ventilation, courtyards were not applied for the new building because these spaces were not completely suitable for hot-humid climate. Consequently, open and semi-open spaces were installed instead of courtyards to be more useful for this climate. In addition, new technological structures and new materials are used in architectural design with respect of changed life style during the second period of British era. The houses have compact plan with joining the service areas like kitchen, toilet and bath. Use of terraces, balconies, and gardens became more usual in designing instead central yards. Reinforced concrete is applied as a structural system contributes thermal mass of the building to decrease heat gains. The physical characteristics of windows were improved to provide suitable natural lighting and ventilation for indoor spaces. According to sun direction and appropriate space location, the sitting and dining room was located at the south façade with large glass windows to catch most of natural lighting. 


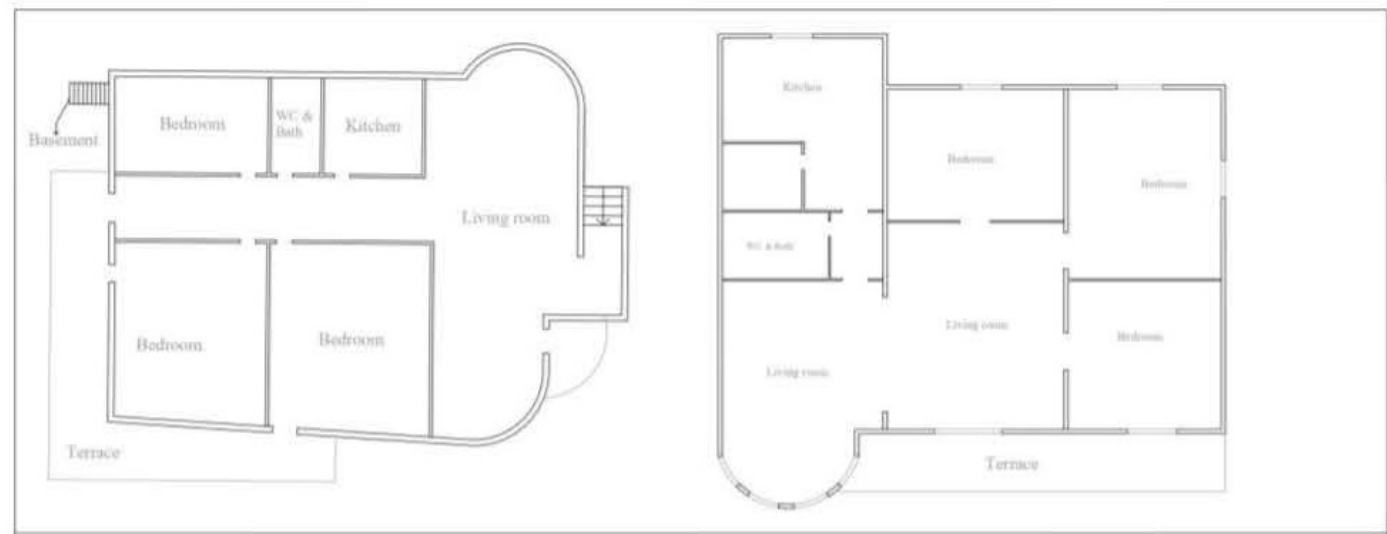

Plans of the houses become more compact.

Balcony: Use of balcony \& Veranda as semi-open spaces are more effective for Cyprus climate.

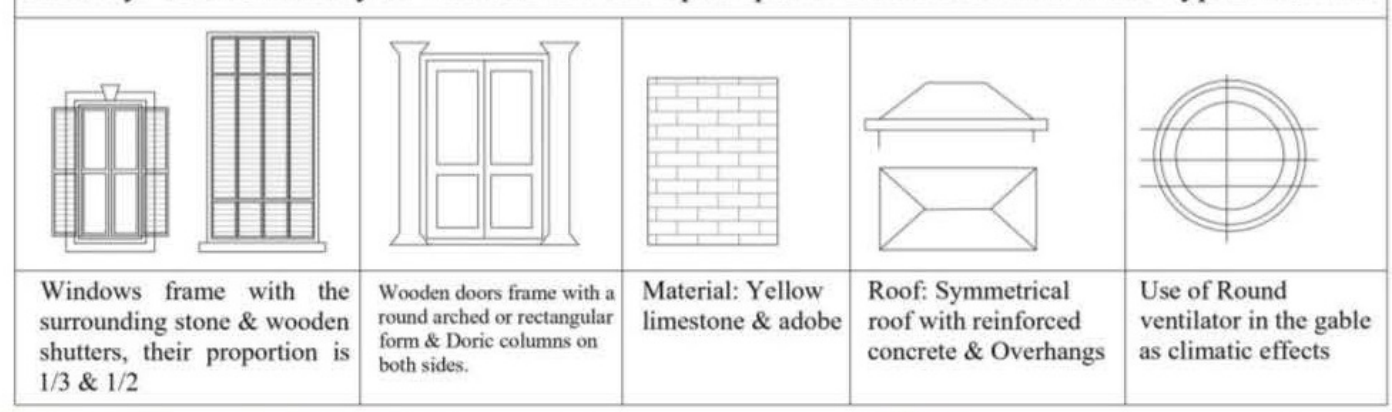

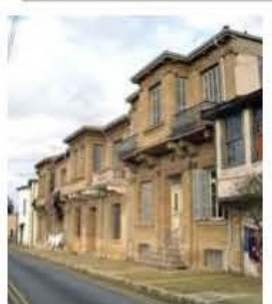

1

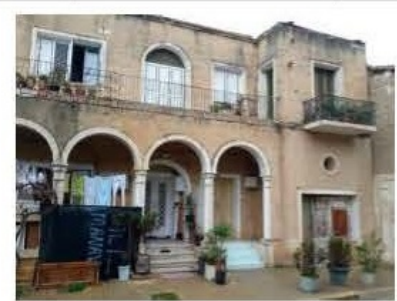

2

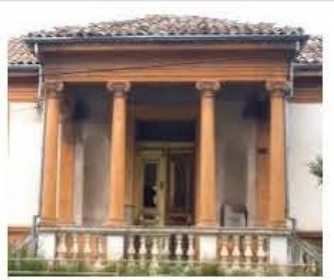

3

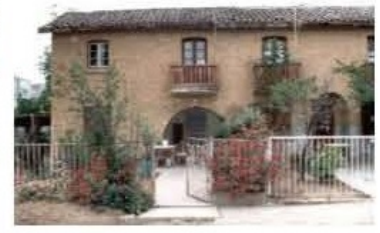

4

1) Houses design of the first era of British Period (Ozay, 2005);

2) House facade in First British period (Sokhanvar 2014)

3) Dentil comice and Doric columns (Sokhanvar, 2014)

4) A typical house with Yellow stone as material for the second British Period (Ozay, 2005)

Figure 7. Characteristics of houses in the British Period (Developed by Researcher)

\subsection{From British Period to Present as the Modern Period}

When the British period finished, the Republic of Cyprus was organized in 1960 as the modern period. In the early ten years of the period, the houses are constructed in one or two floors with use of reinforced concrete as the structure. Most of designers emphasized on shading elements, landscaping, good orientation of building in site and the area of windows as climatic factors to achieve the strategies of passive solar energy (Figure 8). 


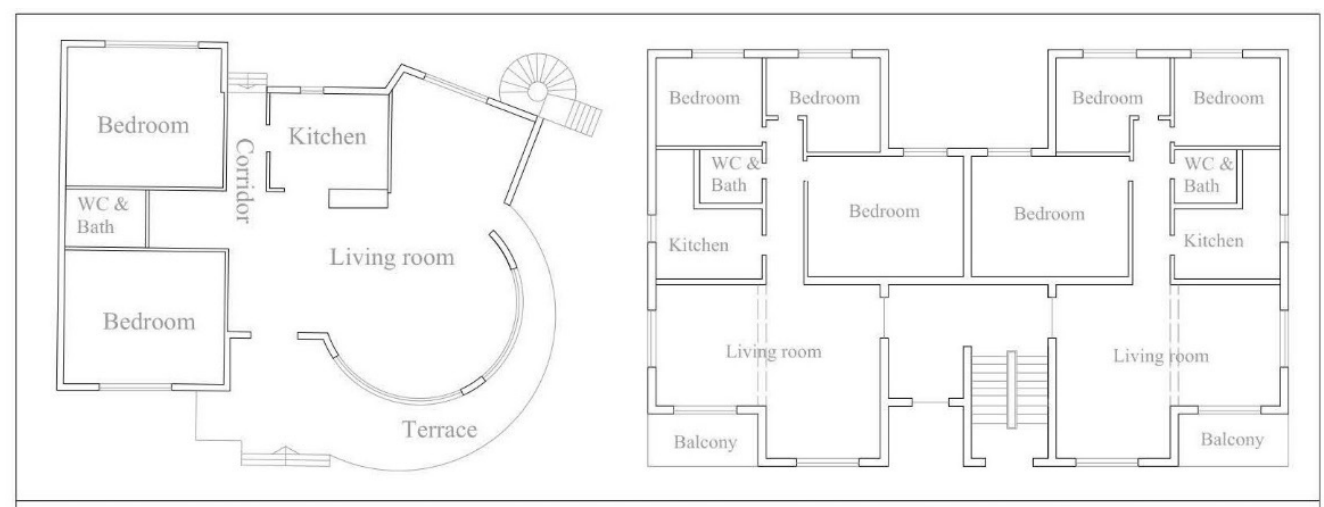

After 1960s: One and two-storey houses, Use of the local materials and traditional techniques, Increasing use of reinforce concrete in the structures.

In 1970s: Spreading apartment type as residential units; Use of flat roofs as different point and inclined climate design.

During 1980-1990: The growth population increase designing of social housing. Also, in later time different types of housing such as two-storey row houses, apartments and detached houses were designed.

From 1990s till now: Increasing mass social housing and 3 or 4-storey housing blocks with same sizes and functional spaces and different type of houses based on the life style and requirements.

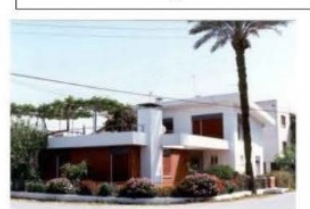

1

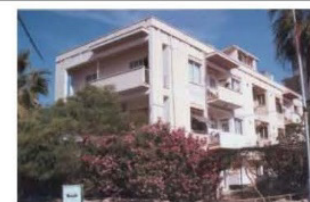

2

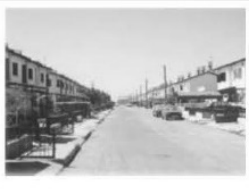

3

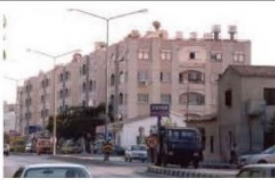

4

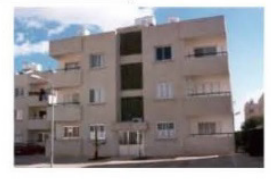

5

1) A type of design housing in 1960 s (Ozay, 2005)

2) An apartment block in 1970 s (Ozay, 2005)

3) A typical of the row-type social housing design in 1980s (Oktay, 2002)

4) Apartment Type Social Housing design (Ozay, 2005)

5) A mass social housing apartment unit (Ozay, 2005)

Figure 8. The evolution of housing design types in the modern Period (Developed by Researcher)

All figures are to be sequentially numbered with Arabic. energy.

Additionally, constructing apartment, flats and detached houses is increasing to be able to answer the initial requirement of Cypriot people after 1980 because of dramatically population growth [32]. Unfortunately, effective passive strategies are ignored and the level of climatic comfort is decreasing in building spaces like good orientation, space location, vegetation, suitable shading devices and selected unsuitable material. Comfortable and cultural spaces follow climatic consideration in the housing such as open and semi-open spaces where is eliminated especially for low- and middle-income people. Wide windows cause to increase the heat gain and moisture in the housing. Use of aluminium window is the only positive climatic consideration in this period because the type of material can absorb heating of sun radiation during summer. Therefore, the majority of people are using electrical and mechanical devices for catching comfortable indoor spaces because of ignoring essential passive considerations [33]. In consequence, people are facing many basic problems such as; 1) increasing cost of energy, 2) decreasing social and environmental consideration in terms of enhancing $\mathrm{Co} 2$ emission, 3) declining the quality of life and 4) ignoring the future generation needs of fuel

\section{Discussions and Conclusions}

This study has set up a consideration about the fundamental passive strategies with respect of environmental and climatic aspect in Famagusta also, an evaluation on the Cypriot housing in different architectural period in order to consider the applying passive strategies in the city.

At the first part of study, according to climate of Famagusta (sun direction, prevailing wind) and responsibility towards our environment, the major passive methods are addressed:

- Good orientation and appropriate location of various spaces according to their functions to catch natural lighting and cross ventilation;

- Considering suitable location and area for windows and opening;

- Installing suitable shading elements to provide sun control and decrease heat gain;

- Use of suitable vegetation and landscaping to provide comfortable indoor spaces as a shading elements and healthy ventilation; 
- Applying suitable materials with light color to contribute the performance of thermal mass;

- $\quad$ Prevention wasting of energy by installing thermal insulation towards inner layer.

In addition, it is obvious that passive solar strategies were able to provide comfortable indoor spaces for the users; unfortunately, they are ignored in contemporary. In the third section of the research, passive solar strategy is evaluated during different periods of architectural housing in Famagusta. Table 1 is illustrated the finding of this evaluation and it is listed all negative and positive points which are reflect passive solar strategies during different eras.

The absence of contribution of the indicators in the first stage is completely obvious in Famagusta City, although the passive solar design parameters are potential point in the city. After population booms and demonstrating their primary requirements, construction of building has dramatically growth with lack of climatic considerations. Therefore, the processing decreases the quality of life and causes many problems for human. As it is visible previously (Figure 1), Famagusta has strong potential to catch important passive methods in order to provide comfortable indoor temperature with the lowest use of fuel energy. According to local climate and environmental impact with respect of socio-cultural factors in the city, the Passive solar housing should be applied to achieve not only, durability for the building but also, suitable life cycle cost for the users. Passive methods must take into consideration during contemporary building design and construction stages as previous time to increase the quality of life with respect of future generation. In order to provide better quality for building, it is suggested that designers must be constructed passive housing development process that they contribute socially and culturally suitable houses in present.

Table 1. Evaluation of Passive Solar Strategies in Cypriot Dwelling from Past Until Present (Developed by Researcher)

\begin{tabular}{|c|c|c|}
\hline \multicolumn{3}{|l|}{$1^{\text {st }}$ part of paper } \\
\hline \multirow{6}{*}{$\begin{array}{l}\text { Passive Solar } \\
\text { Housing Design } \\
\text { Parameters }\end{array}$} & \multicolumn{2}{|l|}{ Building Orientation and Space Location } \\
\hline & \multirow{2}{*}{ Physical Characteristics of Windows } & Suitable location and Area \\
\hline & & Installing suitable shading \\
\hline & \multirow{3}{*}{$\begin{array}{l}\text { Effective Parameters on the Performance of Thermal } \\
\text { Mass }\end{array}$} & Use of suitable vegetation and landscaping \\
\hline & & Applying suitable materials \\
\hline & & $\begin{array}{l}\text { Applying suitable place for installing thermal } \\
\text { insulation }\end{array}$ \\
\hline \multicolumn{3}{|c|}{$2^{\text {nd }}$ part of paper: Passive design Parameters of Famagusta through different periods } \\
\hline & Positive Indicators & Negative Indicators \\
\hline $\begin{array}{l}\text { Ottoman period } \\
\quad(1571-1878)\end{array}$ & $\begin{array}{l}\text { Impact plan and urban structure } \\
\text { Use of Suitable material } \\
\text { Utilize vegetation as shading elements } \\
\text { Installed porch }\end{array}$ & $\begin{array}{l}\text { Ignored good orientation } \\
\text { Small windows } \\
\text { Ignored suitable location for different space } \\
\text { Courtyards }\end{array}$ \\
\hline $\begin{array}{l}\text { British Period } \\
(\mathbf{1 8 7 8 - 1 9 6 0 )}\end{array}$ & $\begin{array}{l}\text { Good orientation } \\
\text { Appropriate space location } \\
\text { Impact plan and urban structure } \\
\text { Improving material building and structure } \\
\text { Utilize vegetation as shading elements } \\
\text { Installing open and semi-open spaces instead of courtyard } \\
\text { Suitable windows areas } \\
\text { Use of shading elements } \\
\text { Choosing suitable color for material of roof and walls }\end{array}$ & Ignored suitable location for windows \\
\hline $\begin{array}{l}\text { Modern Period } \\
\text { (1960-present) }\end{array}$ & $\begin{array}{l}\text { Utilize suitable windows material (Aluminium) } \\
\text { Appropriate space location }\end{array}$ & $\begin{array}{l}\text { Lack of good orientation } \\
\text { Ignored suitable location and areas for windows } \\
\text { Lack of vegetation and suitable shading devices } \\
\text { Decreasing use of appropriate and suitable material } \\
\text { Eliminated valuable spaces in providing solar } \\
\text { insulation like open space, semi-open spaces, and } \\
\text { porch }\end{array}$ \\
\hline
\end{tabular}




\section{REFERENCES}

[1] N. Ozay. A comparative study of climatically responsive house design at various periods of Northern Cyprus architecture. Building and environment, 40(6), 841-852, 2005. https://doi.org/10.1016/j.buildenv.2004.08.024

[2] R. Rahbarianyazd \& L. Raswol. Evaluating energy consumption in terms of climatic factors: A case study of Karakol residential apartments, Famagusta, North Cyprus. Journal of Contemporary Urban Affairs, 2(1), 45-54, 2018. https://doi.org/10.25034/ijcua.2018.3658

[3] M. Nikoofam \& A. Mobaraki. In Pursuit of Sustainable Strategic Long-term Planning Throughout Meta-postmoder nism as New Perspective of Stylistic Design. Journal of Contemporary Urban Affairs, 1(1), 44-55, 2017. https://doi.org/10.25034/1761.1(1)45-55

[4] G., Herrera-Sánchez \& V. M. Garcia-Izaguirre. Habitability, a Basic Premise for Home Design and Its Impact on the Curricula of Architecture Schools. Civil Engineering and $\begin{array}{lll}\text { Architecture, } & 8(5): & 950-962,\end{array}$ https://doi.org/10.13189/cea.2020.080522

[5] C. Koroneos, P. Fokaidis \& N. Moussiopoulos. Cyprus energy system and the use of renewable energy sources. Energy, 30(10), 1889-1901, 2005. https://doi.org/10.1016/j. energy.2004.11.011

[6] A. Saymanlier. Climatic aspects of spaces in Cypriot Vernacular architecture, Published Master Thesis, Eastern Mediterranean University, Gazimagusa, Cyprus, 2001. https://www.amazon.com/Climatic-Aspects-Spaces-Vernac ular-Architecture/dp/3845410248

[7] K. Rabah. Development of energy-efficient passive solar building design in Nicosia Cyprus. Renewable energy, 30(6), 937-956, 2005. https://doi.org/10.1016/j.renene.2004.09.00 3

[8] A. Shandilya, M. Hauer, \& W. Streicher. Optimization of Thermal Behavior and Energy Efficiency of a Residential House Using Energy Retrofitting in Different Climates. Civil Engineering and Architecture, 8(3): 335-349, 2020. https://doi.org/10.13189/cea.2020.080318

[9] R. M., Pulselli, E., Simoncini, \& N. Marchettini. Energy and emergy based cost-benefit evaluation of building envelopes relative to geographical location and climate. Building and Environment, 44(5), 920-928, 2009. https://doi.org/10.1016 /j.buildenv.2008.06.009

[10] B., Andersson, W., Place, R., Kammerud, \& M. P., Scofield. The impact of building orientation on residential heating and cooling. Energy and buildings, 8(3), 205-224, 1985. https://doi.org/10.1016/0378-7788(85)90005-2

[11] I., Spanos, M., Simons, \& K. L. Holmes. Cost savings by application of passive solar heating. Structural Survey, 2005. https://doi.org/10.1108/02630800510593684

[12] A. K. Athienitis. Thermal analysis and design of passive solar buildings. Routledge, 2013. https://doi.org/10.4324/9 781315074351

[13] T. Kalema, G. Jóhannesson, P. Pylsy, \& P. Hagengran,
Accuracy of energy analysis of buildings: a comparison of a monthly energy balance method and simulation methods in calculating the energy consumption and the effect of thermal mass. Journal of Building Physics, 32(2), 101-130, 2008. https://doi.org/10.1177/1744259108093920

[14] M. Santamouris, C. A Balaras, E. Dascalaki, A. Argiriou, \& A. Gaglia. Energy conservation and retrofitting potential in Hellenic hotels. Energy and Buildings, 24(1), 65-75, 1996. https://doi.org/10.1016/0378-7788(95)00963-9

[15] J. Morrissey, T. Moore, \& R. E. Horne. Affordable passive solar design in a temperate climate: An experiment in residential building orientation. Renewable Energy, 36(2), 568-577, 2011. https://doi.org/10.1016/j.renene.2010.08.01 3

[16] B.M Piquer. "A Strategy for Sustainable Development of the Built Environment for the Mediterranean Climate". Published Master thesis MSc in Energy Systems and the Environment, Department of Mechanical Engineer, University of Strathclyde, 2003. http://www.esru.strath.ac.u k/Documents/MSc_2003/piquer.pdf

[17] B. Vale., R. Vale. "Green Architecture: Design for an Energy Conscious Future”, Bulfinch Press, Little Brown and Company, Boston, 1991.https://www.google.com/book $\mathrm{s} ? \mathrm{hl}=\mathrm{en} \& \mathrm{lr}=\& \mathrm{id}=\mathrm{OmWvBAAAQBAJ} \& \mathrm{oi}=$ fnd $\& \mathrm{pg}=\mathrm{PA} 318$ $\& \mathrm{dq}=\% \mathrm{E} 2 \% 80 \% 9 \mathrm{CGreen}+$ Architecture:+Design + for $+\mathrm{an}+$ Energy+Conscious+Future $\%$ E2\%80\%9D\&ots=voeA_3Z8r P\&sig=HYDAmYmY3S7Mo7-IMBqLJoGc1k8

[18] H. Akbari. Shade trees reduce building energy use and CO2 emissions from power plants. Environmental pollution, 116, S119-S126, 2002. https://doi.org/10.1016/s0269-7491(01)0 0264-0

[19] H. M. Sachs, W. Lin, \& A. K. Lowenberger. Emerging energy saving-HVAC technologies and practices for the buildings sector. American Council for an Energy-Efficient Economy, 2009. https://www.aceee.org/sites/default/files/p ublications/researchreports/A092.pdf

[20] R.V. Ralegaonkar, R. Gupta, "Review of intelligent building construction: A passive solar architecture approach", Renewable and Sustainable Energy Reviews, 2010. https://doi.org/10.1016/j.rser.2010.04.016

[21] C. A. Balaras. The role of thermal mass on the cooling load of buildings. An overview of computational methods. Energy and buildings, 24(1), 1-10, 1996. https://doi.org/10. 1016/0378-7788(95)00956-6

[22] L. P. Lukose, Global Warming and Climate Change: A Critique on International Law and Policy. Journal of Contemporary Urban Affairs, 1(3), 38-42, 2017. https://doi.org/10.25034/ijcua.2018.3677

[23] A. M. Khudhair \& M. M. Farid. A review on energy conservation in building applications with thermal storage by latent heat using phase change materials. Energy conversion and management, 45(2), 263-275, 2004. https://doi.org/10.1016/s0196-8904(03)00131-6

[24] N. Lechner, Heating, cooling, lighting: Sustainable design methods for architects. John wiley \& sons, 2014. http://www.academia.edu/download/52814256/Book_Revie w_No.1.pdf

[25] S. Ilter, Exploring Design Principles of Bioclimatic 
Architecture and Double Skin Facades as A Convincing Tool for Energy Saving. Journal of Contemporary Urban Affairs, 2(3), 60-66, 2018. https://doi.org/10.25034/ijcua.20 18.4719

[26] D. Oktay. Design with the climate in housing environments: an analysis in Northern Cyprus. Building and Environment, 37(10), 1003-1012, 2002. https://doi.org/10.1016/s0360-13 23(01)00086-5

[27] M. Nikoofam \& A. Mobaraki. Assessment of Quality of Life in the Urban Environment; Case Study: Famagusta, N. Cyprus. Civil Engineering and Architecture, 8(5): 860-872, 2020. https://doi.org/10.13189/cea.2020.080513

[28] M. Fasli \& F. Pakdel, Assessing Laguna District's Spatial Qualities in Gazimagusa, Northern Cyprus. open house international, 35(1), 74, 2010. http://search.proquest.com/o penview/bafab99e1da4ed7795d41e3fec5607b8/1?pq-origsit $\mathrm{e}=\mathrm{gscholar} \& \mathrm{cbl}=456297$

[29] D. Oktay \& K. Pontikis. In pursuit of humane and sustainable housing patterns on the island of Cyprus. The International Journal of Sustainable Development \& World Ecology, 15(3), 179-188, 2008. https://doi.org/10.3843/susd ev.15.3:1

[30] R. Raycheva. Architecture of Residential Buildings in Bulgaria from the Revival Period. Architecture and Urban Planning, 6, 17-24. 2012. https://doi.org/10.7250/aup.2012. 003

[31] W. Dreghorn. Antiquities of Turkish Nicosia. Turgut Durduran, 1979.

[32] G., Ozay \& N. Ozay. The most common defects on housing surfaces in Northern Cyprus, 2005. https://repository.up.ac. za/handle/2263/10450

[33] D. Oktay. Planning housing environments for sustainability: evaluations in Cypriot settlements. Yap1-Endüstri Merkezi Yayınlar1, 2001. https://www.zerobooksonline.com/en/plan ning-housing-environments-for-sustainability-evaluations-i n-cypriot-settlements_29_41258.html?r=11 